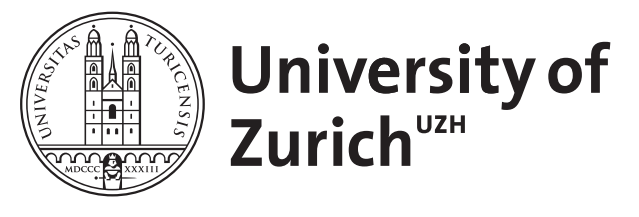

\title{
The sodium phosphate cotransporter family SLC34.
}

\author{
Murer, H ; Forster, I C ; Biber, J
}

\begin{abstract}
This review summarizes the characteristics of the solute carrier family SLC34 that is represented by the type $11 \mathrm{Na} / \mathrm{P}(\mathrm{i})$-cotransporters NaPi-lla (SLC34A1), NaPi-llb (SLC34A2) and NaPi-llc (SLC34A3). Other Na/P(i)-cotransporters are described within the SLC17 and SLC20 families. Type ll $\mathrm{Na} / \mathrm{P}(\mathrm{i})$-cotransporters are expressed in several tissues and play a major role in the homeostasis of inorganic phosphate. In kidney and small intestine, type $11 \mathrm{Na} / \mathrm{P}(\mathrm{i})$-cotransporters are located at the apical sites of epithelial cells and represent the rate limiting steps for transepithelial movement of phosphate. Physiological and pathophysiological regulation of renal and small intestinal epithelial transport of phosphate occurs through alterations in the abundance of type $11 \mathrm{Na} / \mathrm{P}(\mathrm{i})$-cotransporters.
\end{abstract}

DOI: https://doi.org/10.1007/s00424-003-1072-5

Posted at the Zurich Open Repository and Archive, University of Zurich ZORA URL: https://doi.org/10.5167/uzh-1384

Journal Article

Published Version

Originally published at:

Murer, H; Forster, I C; Biber, J (2004). The sodium phosphate cotransporter family SLC34. Pflügers Archiv: European Journal of Physiology (Pflugers Archiv), 447(5):763-767.

DOI: https://doi.org/10.1007/s00424-003-1072-5 


\section{Heini Murer · Ian Forster · Jürg Biber \\ The sodium phosphate cotransporter family SLC34}

Received: 14 January 2003 / Accepted: 28 March 2003 / Published online: 16 May 2003

(C) Springer-Verlag 2003

\begin{abstract}
This review summarizes the characteristics of the solute carrier family SLC34 that is represented by the type $11 \mathrm{Na} / \mathrm{P}_{\mathrm{i}}$-cotransporters $\mathrm{NaPi}-1 \mathrm{la}$ (SLC34A1), NaPillb (SLC34A2) and NaPi-llc (SLC34A3). Other $\mathrm{Na} / \mathrm{P}_{\mathrm{i}^{-}}$ cotransporters are described within the SLC17 and SLC20 families. Type $11 \mathrm{Na} / \mathrm{P}_{\mathrm{i}}$-cotransporters are expressed in several tissues and play a major role in the homeostasis of inorganic phosphate. In kidney and small intestine, type 11 $\mathrm{Na} / \mathrm{P}_{\mathrm{i}}$-cotransporters are located at the apical sites of epithelial cells and represent the rate limiting steps for transepithelial movement of phosphate. Physiological and pathophysiological regulation of renal and small intestinal epithelial transport of phosphate occurs through alterations in the abundance of type $11 \mathrm{Na} / \mathrm{P}_{\mathrm{i}}$-cotransporters.
\end{abstract}

Keywords Sodium-coupled phosphate transport . Type $11 \mathrm{Na} / \mathrm{P}_{\mathrm{i}}$-cotransporters $\cdot$ Endocytosis

\section{Introduction}

The SLC34 family comprises three members: NaPi-lla, $\mathrm{NaPi}-1 \mathrm{lb}$ and NaPi-llc (Table 1). Non-mammalian family members have been identified in various organisms such as flounder and zebra fish, Xenopus laevis, Caenorhabditis elegans, and V. cholerae [42].

Approximately $0.1 \%$ of the total content of phosphate $\left(\mathrm{P}_{\mathrm{i}}\right)$ in the body is contained in the extracellular space. It is essential that the extracellular concentration of $P_{i}$ is held constant at around $1.1 \mathrm{mM}$ for proper cellular functions such as DNA formation and signaling reactions, as well as for bone formation. Members of the SLC34 family are expressed in small intestine and in renal proximal tubules, two important sites that control the extracellular concentration of $\mathrm{P}_{\mathrm{i}}$. It should be noted that extracellular $\mathrm{P}_{\mathrm{i}}$ can be influenced by other mechanisms

\footnotetext{
H. Murer $(\bowtie) \cdot I$. Forster · J. Biber

Institute of Physiology, University of Zürich-Irchel,

Winterthurerstrasse 190, 8057 Zürich, Switzerland

e-mail: hmurer@access.unizh.ch

Tel.: +41-1-6355030/32; Fax: +41-1-6355715
}

such as intra- to extracellular shifts (e.g., from skeletal muscle) which involve other $P_{i}$ transporters, such as members of the SLC20 family. In proximal tubules and enterocytes type $11 \mathrm{Na} / \mathrm{P}_{\mathrm{i}}$-cotransporters are located in the apical membrane and represent the rate limiting steps of transepithelial $\mathrm{P}_{\mathrm{i}}$ transport. In both tissues the abundance of type $11 \mathrm{Na} / \mathrm{P}_{\mathrm{i}}$-cotransporters is controlled by many hormones and metabolic factors according to the body's $P_{i}$ needs. In kidney, several inherited and acquired phosphate wasting disorders affect the abundance of type $11 \mathrm{Na} / \mathrm{P}_{\mathrm{i}}$-cotransporters.

Besides the kidney, expression of NaPi-lla has been described in bone and neurons and in addition to small intestine, expression of NaPi-llb has been described in a number of organs such as lung and mammary glands. In the latter tissues, the detailed physiological and pathophysiological aspects of the type $11 \mathrm{Na} / \mathrm{P}_{\mathrm{i}}$-cotransporters remain to be defined.

In a physiological environment, all SLC34 family members exclusively transport phosphate ions in a obligatory sodium-dependent manner. With the exception of NaPi-1lc, $\mathrm{Na} / \mathrm{P}_{\mathrm{i}}$-cotransport is electrogenic. To date, no specific high-affinity inhibitors are known for this SLC family; phosphonoformic acid (forscanet) at high concentrations (millimolar) inhibits all members. Based on results obtained from hydropathy analysis, cysteine scanning mutagenesis and epitope-tagging studies, a model for the secondary topology of SLC34 transporters has been proposed.

\section{NaPi-Ila (SLC34A1)}

This $\mathrm{Na} / \mathrm{P}_{\mathrm{i}}$-cotransporter was identified by functional expression cloning using $X$. laevis oocytes and a rat and human kidney cDNA library [30]. The major site of expression is principally the renal proximal tubule and here, this protein $(80-90 \mathrm{kDa})$ is localized in microvilli that constitute the brush border membrane. Under normal physiological conditions, the abundance of NaPi-lla is highest in S1 proximal tubular segments of jux- 


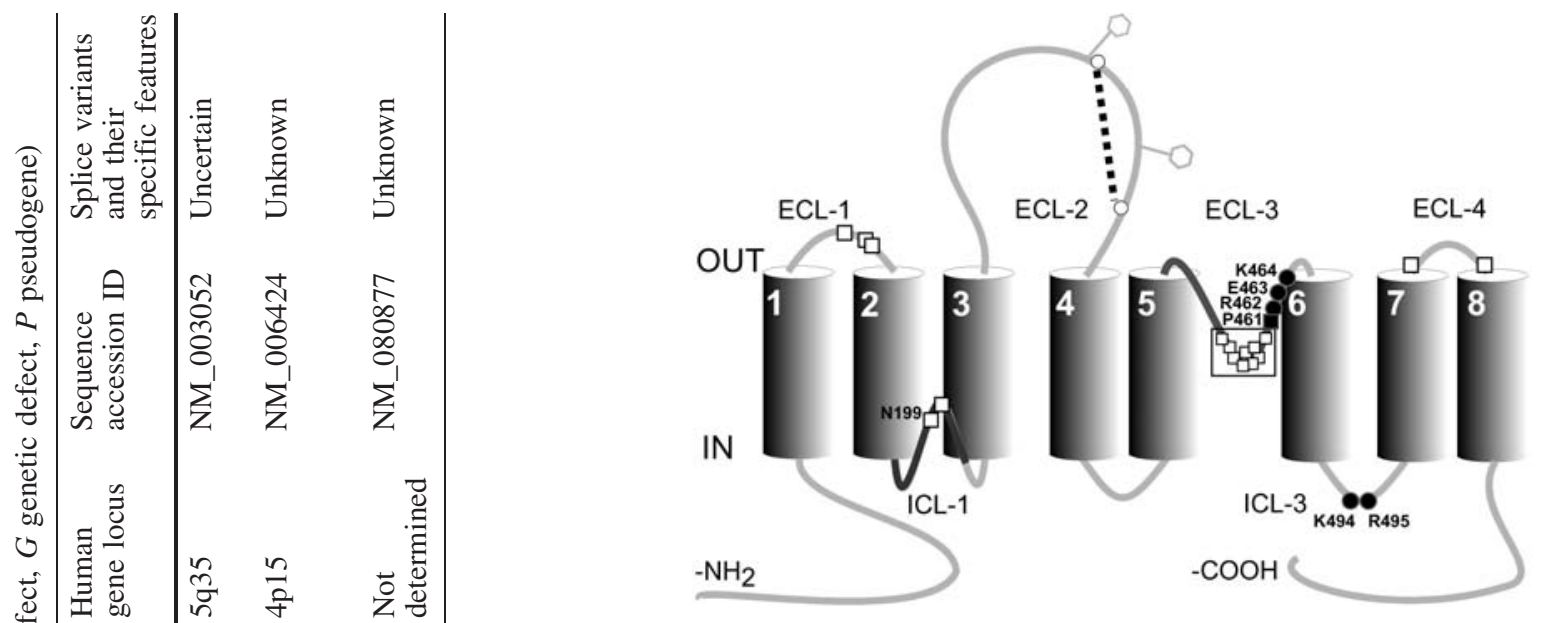

Fig. 1 Secondary topology of the NaPi-lla (SLC34A1) based on current structure-function studies [9]. The protein comprises eight transmembrane domains (TMD1-8) with intracellular $\mathrm{N}$ - and $\mathrm{C}$ termini and a large extracellular loop $(E C L-2)$ containing two Nglycosylation sites (hexagons). An essential disulphide bridge in ECL-2 links each complementary part to form the functional unit. Cysteine scanning mutagenesis has revealed functionally important residues at sites indicated (open squares). Two reentrant loops $(I C L-1, E C L-3)$ are predicted to associate and form the transmembrane cotransport pathway. In ECL-3, proline-461 terminates a 2.5 turn $\alpha$-helix motif (boxed) thought to be an essential part of this pathway, while in ICL-1 asparagine-199 is a critical determinant of transport mode. A triad of three adjacent charge residues (R462, $E 463, K 464)$ in ECL-3 confers part of SLC34 proton sensitivity

tamedullary nephrons [6]. Three different isoforms of $\mathrm{NaPi}-1 \mathrm{la}$ have been reported to exist in proximal tubules as well, yet their function has not been established [39].

$\mathrm{Na} / \mathrm{P}_{\mathrm{i}}$ cotransport by NaPi-lla is electrogenic, involving the inward transfer of one net positive charge per transport cycle. Divalent $\mathrm{P}_{\mathrm{i}}$ is the preferred species and is transported together with three $\mathrm{Na}^{+}$ions $[9,10]$. The substrates (three $\mathrm{Na}^{+}$ions and one $\mathrm{HPO}_{4}{ }^{2-}$ ion) bind in an ordered manner: $\mathrm{Na} / \mathrm{P}_{\mathrm{i}} / 2 \mathrm{Na}$. Typical apparent substrate affinities are: $K_{\mathrm{m}}^{\mathrm{Pi}} \sim 0.1 \mathrm{mM} ; K_{\mathrm{m}}{ }^{\mathrm{Na}} \sim 70 \mathrm{mM}$. In the absence of $\mathrm{P}_{\mathrm{i}}$, the transporter operates in a uniport mode, whereby $\mathrm{Na}^{+}$ions leak according to the electrochemical gradient with a probable stoichiometry of $1 \mathrm{Na}^{+}$ion. Protons interact with the empty carrier and the final Nabinding steps. Higher transport rates are observed at more basic external $\mathrm{pH}$ values [10]. Dependency on $\mathrm{pH}$ has partially been conferred to the charged amino acid motif (REK) contained in the putative extracellular loop ECL3 [7] (Fig. 1).

\section{NaPi-Ilb (SLC34A2)}

NaPi-llb was identified based on EST clones derived from lung tissue $[8,16]$. Expression of NaPi-llb mRNA has been detected in a number of tissues such as small intestine, lung, mammary glands, testis, and liver [43]. By immunofluorescence, NaPi-llb was localized in brush borders of enterocytes, in the apical pole of alveolar type 
11 cells as well as in apical membranes of mammary secretory cells [16, 31, 41]. On Western blots, fully glycosylated NaPi-llb is observed as a band of approximately $108 \mathrm{kDa}$ [16]. Interestingly, in weaning animals $\mathrm{NaPi}-\mathrm{llb}$ was reported to be only partially glycosylated [1].

At the primary sequence level NaPi-llb differs from $\mathrm{NaPi}$-lla mainly in the C-terminus, which is rich in Cys residues and longer by approximately 50 amino acids. $\mathrm{Na} /$ $\mathrm{P}_{\mathrm{i}}$-cotransport is also electrogenic with a likely stoichiometry of $3 \mathrm{Na}: 1 \mathrm{P}_{\mathrm{i}}$ and with $K_{\mathrm{m}}{ }^{\mathrm{Pi}}<50 \quad \mu \mathrm{M}$ and $K_{\mathrm{m}}^{\mathrm{Na}}=40 \mathrm{mM}$. Dependence on $\mathrm{pH}$ is moderate, slightly higher cotransport is observed at more acidic $\mathrm{pH}$ [16].

\section{NaPi-IIc (SLC34A3)}

This member was identified based on human EST clones. Expression of NaPi-llc was found exclusively in kidney and was described as being growth related. The protein $(75 \mathrm{kDa})$ was localized in apical membranes of proximal tubules of deep nephrons. $\mathrm{Na} / \mathrm{P}_{\mathrm{i}}$-cotransport by $\mathrm{NaPi}-1 \mathrm{lc}$ is electroneutral $\left(K_{\mathrm{m}}^{\mathrm{Pi}}=70 \mu \mathrm{M} ; K_{\mathrm{m}}{ }^{\mathrm{Na}}=50 \mathrm{mM}\right)$ and is highly $\mathrm{pH}$ dependent, exhibiting higher transport at more alkaline $\mathrm{pH}[36]$.

\section{Structural aspects of type II $\mathrm{Na} / \mathrm{P}_{\mathrm{i}}$-cotransporters}

As predicted from structure-function studies [10, 26], each type $11 \mathrm{Na} / \mathrm{P}_{\mathrm{i}}$-cotransporter protein most likely spans the membrane eight times. Both $\mathrm{N}$ - and $\mathrm{C}$-termini are located cytoplasmatically and there are multiple $\mathrm{N}$ glycosylation sites in a large extracellular loop. Furthermore, two short (extracellular and intracellular) loops have been postulated to be important functional regions for the transport pathway [10, 24]. A model of the secondary structure of SLC34 Na/ $\mathrm{P}_{\mathrm{i}}$-cotransporters is depicted in Fig. 1. This model is based on data obtained with NaPi-1la (SLC34A1), but appears to be valid for the other family members as well, since in all members, the transmembranous regions are over $80 \%$ identical and exhibit the same hydropathy profile [10]. The largest dissimilarities are found in the $\mathrm{N}$ - and $\mathrm{C}$-termini and in the large extracellular loops. Based on results obtained with tandem constructs of NaPi-lla, it is assumed that the monomeric form is sufficient for full type 1l-mediated $\mathrm{Na} /$ $\mathrm{P}_{\mathrm{i}}$ cotransport [23].

\section{Physiological, pathological and pharmaceutical aspects}

The concentration of the extracellular $\mathrm{P}_{\mathrm{i}}$ is controlled by the body's need, and in adults it is kept constant at around $1.1 \mathrm{mM}$. This is achieved largely by a control of the renal capacity to reabsorb $\mathrm{P}_{\mathrm{i}}$ from the primary urine and, to a lesser extent, by a control of small intestinal absorption of $\mathrm{P}_{\mathrm{i}}$ (see below). Expression of SLC34 members was also

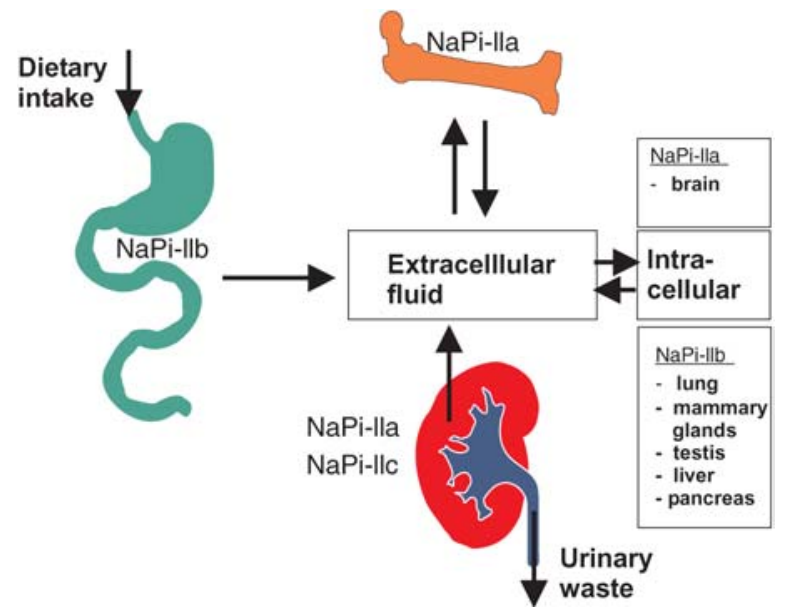

Fig. 2 Sites of expression of type $11 \mathrm{Na} / \mathrm{P}_{\mathrm{i}}$-cotransporters (SLC34). Whereas the roles of NaPi-lla and NaPi-llb in epithelia of renal proximal tubules and small intestine are well described (see text for references) the roles of SLC34 cotransporters in other tissues (indicated in boxes) are less well defined

described in other tissues such as bone [13], brain [17], mammary glands [31], and lung [8, 41] (Fig. 2); however, the physiological roles of type $11 \mathrm{Na} / \mathrm{P}_{\mathrm{i}}$-cotransporters described at these sites have not yet been entirely defined. In type 11 alveolar cells, NaPi-llb was localized in the apical membrane and may be involved in the reabsorption of $P_{i}$ contained in the surfactant. In secreting mammary glands, a role of NaPi-llb could be envisaged in delivering $\mathrm{P}_{\mathrm{i}}$ into milk during lactation.

SLC34A1 and SLC34A3 and renal reabsorption of phosphate

The importance of NaPi-lla in the renal handling of $\mathrm{P}_{\mathrm{i}}$ was demonstrated by a Npt2 knock out mouse [4]. $\mathrm{Npt} 2^{-/-}$ mice exhibit severe hypophosphatemia that is explained by an approximately $70 \%$ decrease of brush-border membrane $\mathrm{Na} / \mathrm{P}_{\mathrm{i}}$ cotransport. The remaining $\mathrm{Na} / \mathrm{P}_{\mathrm{i}}$ cotransport activity has been attributed to NaPi-llc.

Both NaPi-lla and NaPi-llc are targets for the adjustment of renal reabsorption of $\mathrm{P}_{\mathrm{i}}$ and are regulated by many different hormones (e.g., parathyroid hormone) and metabolic factors (e.g., $\mathrm{P}_{\mathrm{i}}$ diet or acidosis) $[33,36,38]$. Furthermore, factors derived from tumors associated with osteomalacia (e.g., FGF23) have been implicated to regulate NaPi-lla in proximal tubules $[11,25,40]$. Regulation of proximal tubular reabsorption of $P_{i}$ was described as being due to an alteration of the abundance of NaPi-lla or NaPi-llc proteins residing in the brushborder membrane. It is assumed that at a constant rate of the de-novo synthesis, the amount of NaPi-lla is altered by regulated endocytosis [33]; so far, no such mechanism has been reported for NaPi-llc. In contrast to other regulated membrane transport processes, internalized NaPi-lla proteins do not recycle, but undergo lysosomal degradation $[20,28,34]$. Although many aspects of the 
signaling cascades, such as the involvement of cAMP and cGMP and different protein kinases have been described $[2,3,33]$, neither the precise mechanisms of the internalization of NaPi-lla nor the mechanisms involved in the vesicular trafficking of internalized NaPi-lla proteins have been defined. With respect to hormonemediated endocytosis of NaPi-lla, a dibasic amino acid motif (RK) within the putative intracellular loop ICL3 was shown to be important as after mutations at this site $\mathrm{NaPi}$-lla was no longer responsive to parathyroid hormone [18].

Acute (2-4 h) and chronic (days to weeks) $\mathrm{P}_{\mathrm{i}}$ depletion has been shown to increase the level of NaPi-lla [21, 27]. In case of chronic $P_{i}$ depletion a posttranscriptional mechanism has been suggested involving $-\mathrm{P}_{\mathrm{i}}$ renal proteins to stabilize NaPi-lla mRNA [32].

Recent data have demonstrated that in renal proximal cells, NaPi-lla interacts with the PDZ proteins NHERF-1 and PDZK1 [12]. Such interactions appear to be important for correct apical sorting and or positioning of NaPilla, as shown by a NHERF-1 knock out model [37] and by studies in OK cells [15]. On the other hand, PDZK1 $1^{-1-}$ mice do not show any changes of NaPi-lla content, suggesting a possible redundancy of other PDZ interactions [22].

Several renal wasting disorders have been described that are based on changes of the expression of NaPi-lla [40]. Studies related to the inherited disorders XLH (Xlinked hypophosphatemia) and ADHR (autosomal dominant hypophosphatemic rickets) and studies related to the acquired disorder $\mathrm{OHO}$ (oncogenic hypophosphatemic osteomalacia) revealed evidence that the two genes PHEX and FGF23 play important roles in determining the abundance of NaPi-lla in renal proximal tubules [11, 25, 40]. Recently, two naturally occurring mutants of NaPi-lla (positions 48 and 147) have been identified and linked to two cases of renal wasting disorders of phosphate [35].

\section{SLC34A2 and intestinal absorption of phosphate}

Several observations provided evidence that NaPi-llb is involved in transcellular flux of phosphate in small intestine $[14,16,19,44]$. Therefore small intestinal NaPillb could represent a possible target for treatment of hyperphosphatemia as often observed in dialysis patients. The most prominent regulators of NaPi-llb in small intestine are 1,25-(OH) $)_{2}$-vitaminD3 and low-phosphate diet. Upregulation of NaPi-llb induced by these factors is manifested by an increase of the protein abundance and appears, in adults, to be nontranscriptional $[14,19,44]$. Furthermore, regulation of NaPi-llb in small intestine by EGF [43], glucocorticoids [1], thyroid hormone [5], and stanniocalcin 1 [29] has been reported.

Acknowledgements We thank the Swiss Science National Foundations and other Swiss financial institutions for their financial support.

\section{References}

1. Arima K, Hines ER, Kiela PR, Drees JB, Collins JF, Ghishan FK (2002) Glucocorticoid regulation and glycosylation of mouse intestinal type $1 \mathrm{lb} \mathrm{Na}-\mathrm{P}_{\mathrm{i}}$ cotransporter during ontogeny. Am J Physiol 283:G426-G434

2. Bacic D, Hernando N, Traebert M, Lederer E, Völkl H, Biber J, Kaissling B, Murer H (2001) Regulation of the renal type $11 \mathrm{Na} /$ $\mathrm{P}_{\mathrm{i}}$-cotransporter by cGMP. Pflugers Arch 442:782-790

3. Bacic D, Schulz N, Biber J, Kaissling B, Murer H, Wagner CA (2003) Involvement of the MAPK-kinase pathway in the PTH mediated regulation of the proximal tubule type $11 \mathrm{Na} / \mathrm{P}_{\mathrm{i}}$ cotransporter in mouse kidney. Pflugers Arch 446:52-60

4. Beck L, Karaplis AC, Amizuka N, Hewson AS, Ozawa H, Tenenhouse HS (1998) Targeted inactivation of Npt2 in mice leads to severe renal phosphate wasting, hypercalciuria and skeletal abnormalities. Proc Natl Acad Sci USA 95:5372-5377

5. Cross HS, Debiec H, Peterlik M (1990) Mechanism and regulation of intestinal phosphate absorption. Miner Electrolyte Metab 16:115-124

6. Custer M, Lötscher M, Biber J, Murer H, Kaissling B (1994) Expression of $\mathrm{Na} / \mathrm{P}_{\mathrm{i}}$ cotransport in rat kidney: localization by RT-PCR and immunohistochemistry. Am J Physiol 266: F767F774

7. De la Horra C, Hernando N, Lambert G, Forster I, Biber J, Murer $\mathrm{H}$ (2000) Molecular determinants of $\mathrm{pH}$ sensitivity of the type lla Na/ $\mathrm{P}_{\mathrm{i}}$-cotransporter. J Biol Chem 275:6284-6287

8. Field JA, Zhang L, Brun KA, Brooks DP, Edwards RM (1999) Cloning and functional characterization of a sodium-dependent phosphate transporter expressed in human lung and small intestine. Biochem Biophys Res Commun 258:578-582

9. Forster IC, Loo DDF, Eskandari S (1999) Stoichiometry and $\mathrm{Na}^{+}$-binding cooperativity of rat and flounder renal type II $\mathrm{Na}^{+}$ $\mathrm{P}_{\mathrm{i}}$-cotransporters. Am J Physiol 276:F644-F649

10. Forster IC, Köhler K, Biber J, Murer H (2002) Forging the link between structure and function of electrogenic cotransporters: the renal type 1la $\mathrm{Na} / \mathrm{P}_{\mathrm{i}}$ cotransporter as a case study. Prog Biophys Mol Biol 80:69-108

11. Fukumoto S, Yamashita T (2002) Fibroblast growth factor-23 is the phosphaturic factor in tumor-induced osteomalacia and may be phosphatonin. Curr Opin Nephrol Hypertens 11:385-389

12. Gisler SM, Stagljar I, Traebert M, Bacic D, Biber J, Murer H (2001) Interaction of the type IIa $\mathrm{Na} / \mathrm{P}_{\mathrm{i}}$-cotransporter with PDZ proteins. J Biol Chem 276:9206-9213

13. Gupta A, Guo XL, Alvarez UM, Hruska KA (1997) Regulation of sodium-dependent phosphate transport in osteoclasts. J Clin Invest 100:538-548

14. Hattenhauer O, Traebert M, Murer H, Biber J (1999) Regulation of small intestinal Na-phosphate cotransporter $\left(\mathrm{NaP}_{\mathrm{i}}\right.$ type IIb) by dietary phosphate intake. Am J Physiol 277:G756-G762

15. Hernando N, Deliot N, Gisler S, Lederer E, Weinman EJ, Biber $\mathrm{J}$, Murer H (2002) PDZ-domain interactions and apical expression of type lla Na/ $\mathrm{P}_{\mathrm{i}}$-cotransporters. Proc Natl Acad Sci USA 99:11957-11692

16. Hilfiker H, Hattenhauer O, Traebert M, Forster I., Murer H, Biber J (1998) Characterization of a new murine type II sodium-phosphate cotransporter expressed in mammalian small intestine. Proc Natl Acad Sci USA 95:14564-14569

17. Hisano S, Haga H, Li Z, Tatsumi S, Miyamoto KI, Takeda E, Fukuui Y (1997) Immunohistochemical and RT-PCR detection of Na-dependent inorganic phosphate cotransporter $\left(\mathrm{NaP}_{\mathrm{i}}-2\right)$ in rat brain. Brain Res 772:149-155

18. Karim-Jimenez Z, Hernando N, Biber J Murer H (2001) Molecular determinants for apical expression of the renal type IIa $\mathrm{NaP}_{\mathrm{i}}$-cotransporter. Pflugers Arch 442:782-790

19. Katai K, Miyamoto KI, Kishida S, Segawa H, Nii T, Tanaka H, Tani Y, Arai H, Tatsumi S, Morita K, Taketani Y, Takeda E (1999) Regulation of intestinal Na-dependent phosphate cotransporters by a low-phosphate diet and 1,25-dihydroxyvitamin D3. Biochem J 343:705-712

20. Keusch I, Traebert M, Lötscher M, Kaissling B, Murer H, Biber J (1998) Parathyroid hormone and dietary phosphate provoke 
lysosomal routing of the proximal tubular $\mathrm{Na} / \mathrm{P}_{\mathrm{i}}$-cotransporter type II. Kidney Int 54:1224-1232

21. Kilav R, Silver J, Biber J, Murer H, Naveh-Many T (1995) Coordinate regulation of rat renal parathyroid hormone receptor mRNA and Na-Pi cotransporter mRNA and protein. Am J Physiol 268:F1017-F1022

22. Kocher O, Pal R, Roberts M, Cirovic C, Gilchrist A (2003) Targeted disruption of the PDZK1 gene by homologous recombination. Mol Cell Biol 23:1175-1180

23. Köhler K, Forster IC, Lambert G, Biber J, Murer H (2000) The functional unit of the renal type IIa $\mathrm{Na}^{+} / \mathrm{P}_{\mathrm{i}}$ cotransporter is a monomer. J Biol Chem 275:26113-26120

24. Köhler K, Forster IC, Stange G, Biber J Murer H (2002) Identification of functionally important sites in the first intracellular loop of the $\mathrm{Na} / \mathrm{P}_{\mathrm{i}}$-IIa cotransporter. Am J Physiol 282: F687-F696

25. Kumar R (2002) New insights into phosphate homeostasis: fibroblast growth factor 23 and frizzled-related protein-4 are phosphaturic factors derived from tumors associated with osteomalacia. Curr Opin Nephrol Hypertens 11:547-553

26. Lambert G, Traebert M, Hernando N, Biber J Murer H (1999) Studies on the topology of the renal type II $\mathrm{NaP}_{\mathrm{i}}$-cotransporter. Eur J Physiol 437:972-978

27. Levi M, Kempson SA, Lötscher M, Biber J, Murer H (1996) Molecular regulation of renal phosphate transport. J Membr Biol 154:1-9

28. Lötscher M, Scarpetta Y, Levi M, Wang H, Zajicek HK, Biber J, Murer H, Kaissling B (1999) Rapid downregulation of rat renal $\mathrm{Na} / \mathrm{P}_{\mathrm{i}}$-cotransporter in response to parathyroid hormone: role of microtubule rearrangement. J Clin Invest 104:483-494

29. Madsen KL, Tavernini MM, Yachimec C, Mendrick DL, Alfonso PJ, Buergin M, Olsen HS, Antonaccio MJ, Thomson ABR, Fedorak RN (1998) Stanniocalcin: a novel protein regulating calcium and phosphate transport across mammalian intestine. Am J Physiol 274:G96-G102

30. Magagnin S, Werner A, Markovich D, Sorribas V, Stange G, Biber J, Murer H (1993) Expression cloning of human and rat renal cortex $\mathrm{Na} / \mathrm{P}_{\mathrm{i}}$-cotransport. Proc Natl Acad Sci USA 90:5979-5983

31. Miyoshi K, Shillingford JM, Smith GH, Grimm SL, Wagner KU, Oka T, Rosen JM, Robinson GW, Hennighausen L (2001) Signal transducer and activator of transcription (Stat) 5 controls the proliferation and differentiation of mammary alveolar epithelium. J Cell Biol 155:531-542

32. Moz Y, Silver J, Naveh-Many T (2003) Characterization of cisacting element in renal $\mathrm{NaP}_{\mathrm{i}}-2$ cotransporter mRNA that determines mRNA stability. Am J Physiol 284:F663-F670
33. Murer H, Hernando N, Forster I, Biber J (2000) Proximal tubular phosphate reabsorption. Physiol Rev 80:1373-1409

34. Pfister MF, Ruf I, Stange G, Ziegler U, Lederer E, Biber J, Murer H (1998) Parathyroid hormone leads to the lysosomal degradation of the renal type II Na${ }^{+} / \mathrm{P}_{\mathrm{i}}$-cotransporter . Proc Natl Acad Sci USA 95:1909-1914

35. Prie D, Huart V, Bakouh N, Planelles G, Dellis O, Gerard B, Hulin P, Benoue-Blanchet F, Silve C, Grandchamp B, Friedlander G (2002) Nephrolithiasis and osteoporosis associated with hypophosphatemia caused by mutations in the type 2a sodium-phosphate cotransporter. N Engl J Med 347:983-991

36. Segawa H, Kaneko I, Takahashi A, Kuwahata M, Ito M, Ohkido I, Tatsumi S, Miyamoto KI (2002) Growth-related renal type $11 \mathrm{Na} / \mathrm{P}_{\mathrm{i}}$ cotransporter. J Biol Chem 277:19665-19672

37. Shenolikar S, Voltz JW, Minkoff CM, Wade JB, Weinman EJ (2202) Targeted disruption of the mouse NHERF-1 gene promotes internalization of proximal tubule sodium-phosphate cotransporter type IIa and renal phosphate wasting. Proc Natl Acad Sci USA 99:11470-11475

38. Silve C, Friedlander G (2000) Renal regulation of phosphate excretion. In: Seldin DW, Giebisch G (eds) The kidney, physiology and pathophysiology. Lippincott Williams \& Williams, pp 1885-1904

39. Tatsumi S, Miyamoto KI, Kouda T, Motonaga K, Katai K, Ohkido I, Morita K, Segawa H, Tani Y, Yamamoto H, Taketani Y, Takeda E (1998) Identification of three isoforms for the Nadependent phosphate cotransporter $\left(\mathrm{NaP}_{\mathrm{i}}-2\right)$ in rat kidney. $\mathrm{J}$ Biol Chem 273:28568-28575

40. Tennenhouse HS, Sabbagh Y (2002) Novel phosphate-regulating genes in the pathogenesis of renal phosphate wasting disorders. Pflugers Arch 444:317-326

41. Traebert M, Hattenhauer O, Murer H, Kaissling B, Biber J (1999) Expression of a type II sodium-phosphate cotransporter in murine type II alveolar epithelial cells. Am J Physiol 277:L868-L873

42. Werner A, Kinne RKH (2001) Evolution of the Na-P cotransport systems. Am J Physiol 280:R301-R312

43. Xu H, Collins JF, Bai L, Kiela PR, Ghishan FK (2001) Regulation of the human sodium-phosphate cotransporter NaPillb gene promoter by epidermal growth factor. Am J Physiol 280:C628-C636

44. Xu H, Bai L, Collins JF, Ghishan FK (2002) Age-dependent regulation of rat intestinal type $11 \mathrm{~b}$ sodiumm-phosphate cotransporter by $1,25-(\mathrm{OH})_{2}$ vitamin D3. Am J Physiol 282:C487C493 